\title{
Irreponibelt, inkarserert eller strangulert?
}

\author{
Vi har kommet opp i en intens fag- \\ lig diskusjon om noen medisinske \\ termer og håper dere kan hjelpe \\ oss.
}

Et lyskebrokk kan beskrives som irreponibelt eller inneklemt. Er disse begrepene å regne som synonymer eller er det nyanser som vi bør vektlegge? Og hva med begrepet inkarserert - hvordan skiller det seg eventuelt fra inneklemt eller irreponibelt? Er det en gradsforskjell - er et inkarserert brokk en mellomting mellom et inneklemt og et strangulert?

Strangulert er et begrep som vi oppfatter er relatert til endret blodsirkulasjon i et organ som er fanget i en snørefure eller brokk. Omfattes strangulert av noen av de foregående termene, for eksempel inkarserert?

Håper dere kan hjelpe oss ut av en endeløs gjentakende diskusjon.

\section{Kjell Kåre Øvrebø}

kjell.kare.ovrebo@helse-bergen.no

Kjell Kåre Øvrebø (f. 1958) er overlege ved Seksjon for øvre gastroenterologisk kirurgi, Avdeling for gastro- og akuttkirurgi, Kirurgisk klinikk, Haukeland universitetssykehus.

\section{E. Hem svarer:}

Jeg skjønner godt at Øvrebø og hans kolleger kommer i tvil. Alt i 1886 sto det i et medisinsk leksikon om den rotete begrepsbruken. Inkarserert ble brukt på flere forskjellige måter på engelsk, «variously explained by authors», som det sto (1).

Det er fire begreper i spill her: irreponibelt, inneklemt, inkarserert og strangulert. Det er særlig inkarserert som byr på problemer. Det første vi kan slå fast, er at inneklemt er norsk for inkarserert. På latin kalles et inneklemt brokk for hernia incarcerata-incarcerare betyr fengsle, innesperre (2). Det er ingen betydningsnyanser mellom det norske og latinske.

Da gjenstår tre begreper: inkarserert, strangulert og irreponibelt, slik det også fremgår i ICD-10 (3). Et inkarserert brokk er en alvorlig komplikasjon, med økt risiko for at blodtilførselen kompromitteres. Hvis det skjer, er brokket blitt strangulert. Strangulare på latin betyr kvele, man kan høre av ordet at det haster (2).

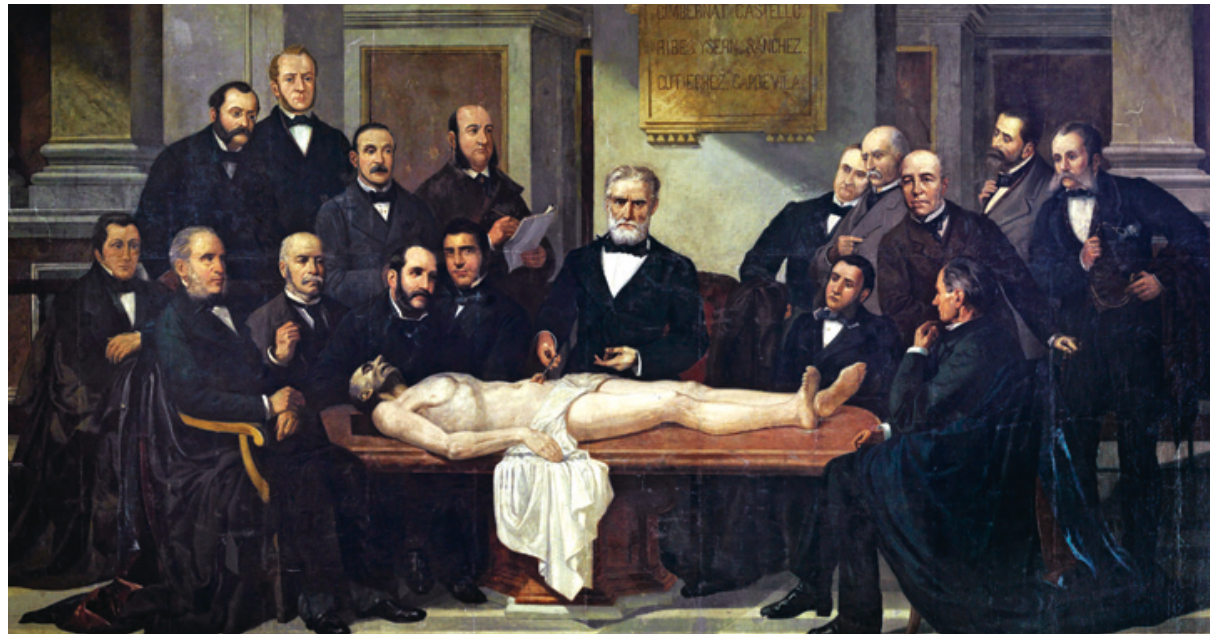

Maleriet av den spanske kirurgen Diego de Argumosa (1792-1865) som demonstrerer brokkirurgi på et kadaver, er en av få kunstneriske fremstillinger av brokk. Oljemaleri av Antonio Bravo (1885). Det medisinske fakultet, Complutense University of Madrid. Science Photo Library

Når et brokk lett glir tilbake ved at man trykker på det, kalles det reponibelt, hernia reponibilis (2). På latin betyr reponere å føre tilbake. Når brokket ikke lar seg presse tilbake, er det blitt permanent eller irreponibelt (4).

Så langt er det greit. Øvrebø spør om irreponibelt og inkarserert betyr det samme. Svaret er nei. Et inkarserert brokk er også irreponibelt, men tilstanden er alvorligere, blodsirkulasjonen står i fare (5). At begrepsbruken er forvirrende, ser vi på engelsk, der man for eksempel kan bruke begrepet irreducible for både irreponible og inkarsererte brokk $(6,7)$.

Grenseoppgangen mellom inkarserert og strangulert brokk er heller ikke alltid helt klar. Forklaringen er nok at det alltid vil være sirkulasjonsforstyrrelser i inkarseratet. Noen ganger oppstår gangren i løpet av få timer, mens i andre tilfeller, når inneklemmingen er lavgradig, vil tarmen bevare sin vitalitet i flere døgn, ifølge Nordisk lcerebok $i$ kirurgi (8). Uansett hvordan inneklemmingen begynner «bliver Forholdet efter nogen Tid det samme», skrev kirurgen Otto Borchgrevink (1856-1928) i 1907 (9). Oftest anvendes derfor uttrykkene inkarserasjon og strangulasjon «i daglig Tale om hinanden» (9). Det er altså et spørsmål om tid før et inkarserert brokk blir strangulert. Et inneklemt brokk bør derfor «urge the surgeon to undertake operation sooner than later» (10).

Oppsummert: Når brokket ikke kan presses tilbake (irreponibelt) og blodsirkulasjonen står i fare (inkarserert), er det et tidsspørsmål før blodtilførselen opphører (strangulert).
Jeg takker Kjetil Søreide for nyttige kommentarer.

Erlend Hem

erlend.hem@medisin.uio.no

Erlend Hem (f. 1970) er dr.med., fagsjef i Klinikk psykisk helse og avhengighet, Oslo universitetssykehus, og redaktør for Tidsskriftets språkspalte.

\section{Litteratur}

1. Incarcerate. I: Oxford English Dictionary. www oed com/view/Entry/93319 (7.9.2015).

2. Nørby S, red. Klinisk ordbog. 16. utg. København: Munksgaard, 2004.

3. Brokk (hernia) (K40-K46). I: ICD-10. Den internasjonale statistiske klassifikasjonen av sykdommer og beslektede helseproblemer. Oslo: Helsedirektoratet, 2011: 595-9.

4. Schlichting E. Brokk. I: Store medisinske leksikon (13.2.2009). https://sml.snl.no/brokk (7.9.2015).

5. Wara P, Sørensen FH. Hernier. I: Stadil F, Lund B, Nordling J, red. Kirurgisk kompendium. Bd. 1. 3. utg. København: Nyt Nordisk Forlag Arnold Busck 2003: 743 .

6. Dorland's illustrated medical dictionary. 31. utg Philadelphia: Saunders Elsevier, 2007: 861-2.

. Irreducible. I: Stor engelsk-norsk ordbok. www.ordnett.no/search?search=irreducible \& lang=en (7.9.2015)

8. Brofeldt SA. Bråck (herniae). I: Ingebrigtsen R, Kjærgaard S, Petrén G, red. Nordisk lærebok i kirurgi. Del 3: Speciel kirurgi (anden del). 3. utg. Kjøbenhavn: Ejnar Munksgaard, 1941: 51-4.

9. Borchgrevink 0. Brok og brok-behandling. Kristiania: Aschehoug, 1907: 92. www.nb.no/nbsok/

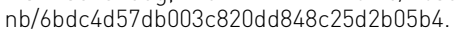
nbdigital? lang=no\#105 (7.9.2015).

10. Bay-Nielsen M. Complications of hernia in general. I: Kingsnorth AN, LeBlanc KA, red. Management of abdominal hernias. 4. utg. London: Springer, 2013: 171 . 